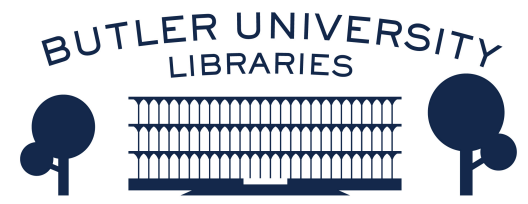

Journal of Hindu-Christian Studies

Volume 6

Article 16

January 1993

\title{
Book Review: "The Christian Institute for the Study of Religion and Society, a Research Arm of Christian Churches in India"
}

Harold Coward

Follow this and additional works at: https://digitalcommons.butler.edu/jhcs

Part of the Religion Commons

\section{Recommended Citation}

Coward, Harold (1993) "Book Review: "The Christian Institute for the Study of Religion and Society, a Research Arm of Christian Churches in India"," Journal of Hindu-Christian Studies: Vol. 6, Article 16. Available at: https://doi.org/10.7825/2164-6279.1085

The Journal of Hindu-Christian Studies is a publication of the Society for Hindu-Christian Studies. The digital version is made available by Digital Commons @ Butler University. For questions about the Journal or the Society, please contact cbauman@butler.edu. For more information about Digital Commons @ Butler University, please contact digitalscholarship@butler.edu. 


\section{The Christian Institute for the Study of Religion and Society, a Research Arm of Christian Churches in India. A. Frank Thompson.} Lewiston, N.Y.: Edwin Mullen Press, 1992, v+164p., n.p.

THE CHRISTIAN INSTITUTE for the Study of Religion and Society (CISRS) was established by The National Christian Council of India in 1957 as a largely Protestant organisation for the purpose of providing a research arm for the churches. For much of its history it has provided a leading edge of engagement with social issues for the Christian Church in India. It is appropriate that some 35 years later an assessment should be made of its impact. This is the task that Frank Thompson takes up in this book. The author also hopes to make the Institute's work more widely known outside India. $\mathrm{He}$ is well qualified for the task. He taught in Kerala in the 1950s and from 1962 to 1970 was on the staff of Bishops College in Calcutta. He was also a longtime friend of Richard Taylor - a leading staff person of the Institute.

Thompson's approach is to review all the publications of the Institute in the context of India's history since the turn of the century. A contemporary slant is provided by examining many of the issues against the recommendations of The Brundtland Report with its concerns for a sustainable world society. Comparison is also made with Indian government policies and with the positions adopted by other Indian research centers such as the William Carey Study and Research Centre. Thompson aims at not only an assessment of the CISRS as a research arm of the Protestant Christian churches in India, but also of the broad engagement of Christianity with worldwide social issues. The author's social and ethical focus is seen in the chapter titles: Dalits, Tribals, Indian Women and the Indian Churches.

The forces that led to the creation of the CISRS were closely related to the gaining of independence in India. The churches wanted to join in the new hope by also working toward a free, united and just India. Accordingly the founding aims of the Institute were threefold: to research social problems, to share the research results with the Christian Churches and to encourage the establishment of Christian social ethics in India. Thompson finds that while the Institute has been reasonably successful in pointing to the changes in India that Christian ethics require, the government, the churches and the Indian society at all levels have largely failed to actualise such changes. However, one area of current concern which the Institute failed to engage was that of the environment. In her report Gro Brundtland emphasised the current environmental crisis, but she also observed the way in which development has led to the exploitation and oppression of peoples.

Thompson finds that the CISRS has, especially in recent years, paid careful attention to the case of the Dalits, a term that includes many of India's oppressed groups Untouchables, Tribals and others, now totaling some $16 \%$ of India's population according to the 1981 Census. In spite of the efforts of Gandhi and Ambedkar, the Institute's many publications on the topic suggest that little has changed. Even within Christian churches there is discrimination against Dalits from those who place themselves in a higher caste - in spite of the fact that such discrimination is clearly against Christian teaching. The CISRS journal Religion and Society devoted an issue to this topic in 1958 under the title 'Caste in Church and Nation'. Thompson notes that in the earliest years, concern with the Dalits was made subservient to the national goal of nation-building. However, increasingly the Institute engaged in action-oriented studies with the Institute's journal Samata devoting 
itself to exposing attacks on Dalits. A 1987 issue of Religion and Society offered studies of situations within Christian churches of Kerala, Tamil Nadu, Andhra, Karnataka and Punjab. The overall conclusion of one scholar was that the lot of most Dalits had not improved, and that in the sharing of power in Christian congregations they are not treated fairly. The Institute's Associate Director, Dr. Abraham Ayrookuzhiel, has focused his research since 1987 on this issue. The next Bulletin will publish one of his most recent papers on the Dalits. In addition to the work of Ayrookuzhiel, Thompson points to the recent formation of The Christian Dalit Liberation Movement in 1948 and its goal of producing a Dalit Theology as a hopeful sign. But to this point Ambedkar's charges of unjust treatment by the Hindu society of his day seem to have remained basically unchanged even in some Christian communities. Thompson concludes his analysis by observing that the Brundtland Report links poverty, such as the Dalits experience in India, with disease, crime and degradation of the environment.

In addition to the Dalits, the CISRS has sought to bring ethical concern to the lot of the adivasis or the Aboriginals of India. Here too the lot of those who have converted to Christianity is given special attention. Indian independence has not brought the aboriginals of India the better future that it seemed to promise. Studies in Religion and Society suggest that since independence a neocolonial exploitation of the Tribals has ensued. Even though the Tribals account for about $15 \%$ of the Christians in India, Christianity has not always brought blessings. Although there have been improvements in education, a fragmentation of Tribal societies has resulted from competing missions. Recently, however, there are signs that tribal leaders are making an effort to overcome particular Christian divisions. A reform movement called Tribal Awakening, led by Christians, is reaffirming a unifying tribal identity. Thompson notes that such a move is in common with aboriginals the world over.
The author then analyses the topic of the CISRS and Indian Women. After reviewing the negative situation women have experienced in Indian society, Thompson highlights the major role played by the Joint Women's Program (JWP) established by the CISRS and the William Carey Study and Research Centre. It has established 'grass roots' activism among both poor and well educated women. Volunteers and trained leaders have instituted effective programs in centres like Bangalore and Bombay. As well, representations have been made at the national level regarding the several areas of women's inequality under law. As such the JWP has been a force for social justice, not only for Christians but for all women in India. Several studies from this work were published in Religion and Society in 1988. The same journal also presented the results of a JWP consultation on the status of women in the various religions of India. In spite of some gains in awareness and improvements in legislation, the situation for most women in India has changed little. Indeed, Thompson concludes his analysis with the observation that in recent years there has been a fundamentalist resurgence in all religions that threatens whatever progress has been made for women. This can be seen in the revival of practices like sati.

The book then turns to a review of the CISRS activity in the academic study of religion. In this regard much attention has been focused on the dialogue between Hindus and Christians. The early work of the Institute scholars - people like M. M. Thomas - may be seen as a declaration by Indian Christians of their Indianness. In his book The Acknowledged Christ of the Indian Renaissance, Thomas reviewed figures from Roy to Gandhi for the impact of Christianity within India. The two quests of the early activities of the Institute are described as 'understanding and compassion' (p.112). The approach of the Institute was to seek out lively minds from various backgrounds for group study. A record of these activities is found in issues of Religion and Society from 
1957 to 1980 and shows two main concerns: the worries of the churches over issues such as conversion, abortion, etc., and the need to understand and relate to contemporary manifestations of the Hindu religion and culture. It was in this latter context that the question of inter-religious dialogue was dealt with. Thompson finds that such dialogue was studied and practiced on three levels in Institute activities: spiritual, conceptual and existential. But the overall aim of the Institute was seen to be the practical one of 'Christian participation in nation-building' (p.121). But within this thrust the moral dimension was not lost. Emphasis on the status of women, the Dalits and oppressions of all kinds appears, especially in Ayrookuzhiel's studies.

The final chapter deals with the CISRS and the Indian Churches. The Institute has consistently offered what might be termed a prophetic critique of the churches - a relentless focus on morality and compassion. Thus the constant engagement of social issues in India. Within the wider world, the work of M. M. Thomas has achieved a high profile with the World Council of Churches. Within India, however, the engagement of other religions has been less successful. As Dick Taylor remarked, it is hard to find Hindus in India interested in dialogue. Outside India where Hindus find themselves in a minority position there seems to be greater openness and interest. Within India the CISRS has worked for unity among the Christian churches with some success. After the early focus on 'nation-building' passed, the churches have begun to come together around moral issues facing Indian society.

In his critique of the work of the CISRS Thompson emphasises two points. First, due to the complex organisational structure, one side of the Institute's activity is sometimes not in touch with other research thrusts. This occurs, suggests the author, due to the involvement of the Institute with 'people at different social levels, confronted with different social problems' (p.148), and is therefore an organisational problem which may not be easy to overcome. He identifies a second and related problem at the level of thought and reflection. While the Institute has brought theological reflection and the people's voice to women's issues (e.g. the JWP), there has been a comparative absence of scientists and reflection on issues such as the environmental crisis. Thompson also claims that since the early ' 80 s there has been a decrease of explicitly theological analysis of issues in Religion and Society. The Institute has, not surprisingly, been unsuccessful in evoking strong response from the Indian Christian churches, and it has not remained in touch with the best of Christian thought elsewhere (p.150). Further, says Thompson, the CISRS exhibits a 'troubling innocence about technology' especially regarding its devastating impact on the environment in India.

The CISRS has been important to the churches. in India, and to scholars of Indian religion. Yet the Institute, in spite of its long history, has not been widely known. Thompson's careful and balanced study not only opens the activity of the Institute to broad knowledge, it also sets its work in the broad context of contemporary global issues - thus prodding the Institute to a wider and more effective engagement with society in the future.

\author{
Harold Coward \\ University of Victoria, \\ Victoria, Canada, V8W 3P4
}

